\title{
Violent Extremism in the Northern Frontier Counties of Kenya: Exploring Human Security as a Sustainable Countering Strategy
}

\author{
Adi Guyo*
}

\begin{abstract}
The contemporary rise of terrorism as a form of violent extremism has led the government to adopt a narrow state-centric security approach to mitigate these threats. Violent extremism compromises peace, security, and communal cohesion, and often thrives on human security deficits such as marginalisation and disenfranchisement from the decision-making processes. The prominence of a state-centric security approach has overshadowed the human security dimension of countering violent extremism, thereby compromising state-society relations. On the contrary, a human security approach which entails freedom from fear and freedom from want, is viewed as a holistic approach to security that secures both the state and society. Less debated, however, is the relationship between countering violent extremism and societal marginalisation as viewed through the lens of human security. This paper argues that the narrow state-centric approach adopted by the Kenyan government in the Northern Frontier Counties has continually marginalised the community living in these counties and is proving unsustainable in countering violent extremism. As a point of departure from this approach, a more human security centred approach is suggested which is likely to be more sustainable in countering violent extremism and more successful in reversing the trend of marginalisation that has arisen from the narrow statecentric approach.
\end{abstract}

Keywords: Northern Frontier Counties, human security, violent extremism, state-centrism, marginalisatio

* The author is an LLB student at Strathmore University Law School in Nairobi, Kenya. She would like to acknowledge her parents for being a constant source of inspiration, love and support.

Vol. 6:1 (2021) p. 195 


\section{Table of Contents}

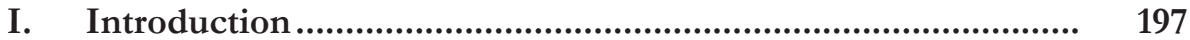

II. Violent Extremism and Human Security ............................... 199

III. Historical Marginalisation of Northern Frontier Counties...... 203

IV. Violent Extremism and Mitigation Measures in NFCs ............ 208

i. Isiolo case study ………………………………………………….... 213

V. Recommendation and conclusion ......................................... 216

i. Recommendations .............................................................................. 216

ii. Conclusion ................................................................................... 218 


\section{Introduction}

Since the 1998 United States Embassy bombing and the September 11, 2001 Al Qaeda attacks in New York and Washington DC, Kenya has been at the frontier of global efforts to counter violent extremism. Kenya is prone to attacks partly because of the presence of predisposing factors such as youth unemployment, radicalisation, and economic disparities, among others. ${ }^{1}$ Further, the country's strategic location in the Horn of Africa has aggravated this situation. The Horn of Africa is a region of fragile geopolitical and security dynamic. ${ }^{2}$ This region has witnessed prolonged conflicts that have led to the state collapse in Somalia in 1991; an eastern neighbour to Kenya bordering three of the Northern Frontier Counties. The collapse of the government led to the absence of government functionaries and created a security vacuum across Somalia. ${ }^{3}$ This provided a perfect condition for the international extremist group to establish and flourish itself through Al Shabaab, to locally perpetrate its agenda in Somalia, the Horn of Africa, and beyond. ${ }^{4}$ While Kenya has managed to navigate through layers of fragility and vulnerability in the Horn of Africa, the emergence of violent extremism has tested the stability of the country due to sustained violent attacks by extremist groups. ${ }^{5}$

The main challenges facing Kenya's security from emerging violent extremist groups in Somalia arises from several factors: firstly, the geographical proximity of the Northern Frontier Counties to Somalia. In particular, the three Counties of Mandera, Wajir and Garissa, which share a border with Somalia, continue to experience spill-over effects of insecurity across the long porous border. ${ }^{6}$ Further, cultural cross-border migration by the nomadic people has been exploited by $\mathrm{Al}$ Shabaab by embedding within the population. ${ }^{7}$ In addition,

Eelco K, Durner T and Schwartz M, 'Violent extremism and instability in the greater Horn of Africa: An examination of drivers and responses, Global Centre on Cooperative Security' 2016, 1 -https:// www.globalcenter.org/wp-content/uploads/2016/05/GCCS_VIOLENT-EXTREMISM_low_3. pdf- on 13 February 2021.

2 Rondos A, 'The Horn of Africa: Its strategic importance for Europe, the Gulf States, and beyond' 6 Horizons: Journal of International Relations and Sustainable Development, 2016, 151.

3 Ramadane Z, 'Somalia: State failure, poverty and terrorism' 6(7) Counter Terrorist Trends and Analyses, 2014, 13-14.

4 Holseth D, 'Al Shabaab - is it the New Al-Qaeda?' 30(1) American Intelligence Journal, 2012, 80-81.

5 United Nations Development Programme, Support to the prevention of violent extremism in Kenya, 1.

6 Castagno A, 'The Somali-Kenyan controversy: Implications for the future' 2(2) The Journal of Modern African Studies, 1964, 167-169.

Mutisya C, 'Conflict in time, petrified in space: Kenya-Somalia border geopolitical conflicts' MA Thesis, Naval Postgraduate School, California, 2017, 67. 
Al Shabaab has politicised to its advantage the prevailing historical fault-lines reinforced by geopolitics, inter-communal relations, and marginalisation of Northern Frontier Counties of Mandera, Marsabit, Isiolo, Wajir and Garissa.

Over the years, Kenya has developed strategies to counter violent extremism. Most often, this strategy entails the use of hard state-centric security mechanisms. ${ }^{8}$ In 2014, security laws were enacted which were met with broad criticism mainly due to concerns that they curtailed civic rights. ${ }^{9}$ The main concern was that the government would use a heavy handed state-centred security approach that would infringe on the citizens' civil and political rights. ${ }^{10}$ Such approaches tend to be narrow and limiting given that the phenomenon of violent extremism is partly motivated by various factors that are rooted in economic, social and security marginalisation. ${ }^{11}$ The use of state-centric security may improve security in the short-term. However, reliance on state-centric security apparatus per se at the expense of long-term human security interventions is most likely unsustainable in the Northern Frontier Counties. This is because as a region that emerged from systemic marginalisation coupled with protracted post-independence conflicts, this state of fragility can be appreciably mitigated via long-term human development.

Violent extremism has been treated as conventional warfare that requires a conventional state-centric approach that mainly involves the police, military, intelligence agencies and criminal justice system. ${ }^{12}$ However, fighting extremists requires a holistic approach with people at the centre of planning and implementation of security strategies. The challenges of a narrow state approach to security have raised a serious scholarly quest on the place of human security in addressing violent extremism. In particular, the impact of the security sector's approach and societal marginalisation viewed from the perspective of human security has not received adequate attention.

Human security is generally about people's freedom from fear and freedom from want. ${ }^{13}$ It offers a bottom-up approach contributing to

\footnotetext{
Life and Peace Institute Centre for Christian-Muslim Relations in Eastleigh, Exploring peaceful coexistence in Nairobi's urban settlements, 2016, 11.

9 Okech A, 'Asymmetrical conflict and human security: Reflections from Kenya' 37(1) Strategic Review for Southern Africa, 2015, 68.

10 Ogolla F, 'The determinants of Kenya's national security policy since independence' University of Nairobi, Nairobi, 2014, 101.

11 Mutisya C, 'Conflict in time, petrified in space: Kenya-Somalia border geopolitical conflicts', 67.

12 Ogolla F, 'The determinants of Kenya's national security policy since independence', 100-102.

13 Jolly R and Deepayan R, The human security framework and national human development reports: A review of experiences and current debates, United Nations Development Programme National Human Development Report Unit, Occasional Paper 5, May 2006, 4, http://hdr.undp.org/sites/ default/files/nhdr_human_security_gn.pdf on 5 August 2020.
}

Vol. 6:1 (2021) p. 198 
discussions on how to tackle the root-causes of unrest and violence by including a multi-layered approach involving the state and society. ${ }^{14}$ The complex threats from violent extremism can be addressed by embracing the human security dimension and focusing on the four pillars of human security relevant to countering violent extremism: economic security, political security, personal security and communal security. The role, relevance, and engagement of youth is cross-cutting in each of these pillars.

This paper explores linkages between violent extremism and historical marginalisation. It argues that the narrow state-centric approaches adopted by the Kenyan government continue to marginalise the people of NFC and that this is proving to be unsustainable in countering violent extremism. The human security approach is considered as a more sustainable and effective strategy to countering violent extremism in the NFCs of Kenya. The paper proceeds as follows: Part II provides an insight into the phenomena of violent extremism and human security as a conceptual framework. Part III explores the history of the Northern Frontier Districts (Counties) in order to provide an understanding of the root causes of marginalisation. Part IV further reflects on the measures used by the government to counter violent extremism and how this has not only continued but also aggravated the marginalisation of this region. Finally, in Part $\mathrm{V}$, the paper provides recommendations before it concludes.

\section{Violent Extremism and Human Security}

Violent extremism has emerged as a global phenomenon, especially after the Cold War, ${ }^{15}$ and has gradually been on the rise in Kenya. The violent impact of these extremist groups emerged in Kenya when Al Qaeda attacked the United States Embassy in Nairobi in 1998. ${ }^{16}$ This was three years before the Al Qaeda attacks in New York and Washington DC in United States on $11^{\text {th }}$ September 2001. ${ }^{17}$ The United States in collaboration with other countries formulated a largely state-centred approach to counter the threats posed by the extremist

14 United Nations, Human Security Unit, Human Security Handbook: An integrated approach for the realization of the Sustainable Development Goals and the priority areas of the international community and the United Nations system, 2016, 10.

15 Shukla S, 'Emerging new trends of terrorism: challenges before the United Nations', 67(1) The Indian Journals of Political Science, 2006, 165.

16 Whitaker B, 'Reluctant partners: Fighting terrorism and promoting democracy in Kenya', 9 (3) International Studies Perspectives, 2008, 257.

17 Jermalavicius T, 'The world after September 11 th: Change and continuity' 1(3) Connections, 2002, 103.

Vol. 6:1 (2021) p. 199 
groups. ${ }^{18}$ Several notions were propagated to explain this emerging phenomenon. This includes Huntington's hypothesis of the 'clash of civilisation', which states that 'the most important distinctions among peoples are (no longer) ideological, political, or economic. They are cultural'. ${ }^{19}$

The cultural aspects conform to the identity-based warfare as espoused by Mary Kaldor, where the pursuit of violence fits into the description of the new war, fighting in the name of identity politics. ${ }^{20}$ In contrast, however, Kaldor's explanation of the new war has a broader perspective including that this form of warfare is characterised by violence between varying combinations of state and non-state networks. This includes attempts to achieve political, rather than physical control of the population through fear and terror; conflict financed not necessarily through the state but through other predatory means that seek the continuation of violence; and furthermore perpetrators that gain economically from identity-based politics that promote intolerance. ${ }^{21}$ In this type of war, violence is often directed towards the civilians as opposed to armed groups. ${ }^{22}$ This explicit description of the actors in the new wars shows their predatory character especially where they target the population to achieve limited political mileage. For them, the control of the population will bring about the need for responsibility for service delivery of which they are ill prepared.

'Extremists' refer to individuals who depart from the mainstream and become extreme in their views and behaviours. ${ }^{23} \mathrm{On}$ the surface, violent extremists appear to be propagated by identity, which is employed to radicalize, and which often leads to ethnic, religious, and regional violence. ${ }^{24}$ It may also be motivated by poverty, exclusion and social injustice. ${ }^{25}$ Furthermore, it is noteworthy that the ability of violent extremists to thrive in any area is driven by the presence of an ungoverned space. The other factor is the ability to capture the hearts and minds of the people by appealing to their conscience, identifying with their problems

18 Whitaker B, 'Reluctant partners: Fighting terrorism and promoting democracy in Kenya', 256, 258.

19 Huntington S, The Clash of Civilizations and the Remaking of World Order, Simon and Schuster, New York, 1996, 21.

20 Kaldor M, New and old wars: Organised Violence in a global era, $3^{\text {rd }}$ ed Cambridge University Press, Cambridge, 2012, 71-72.

21 Kaldor M, 'New and old wars: Organised Violence in a global era', 80-81,209.

22 Kaldor M, 'Peacemaking in an era of new wars' in Thomas de Waal, Think Peace: Essays for an Age of Disorder, Carnegie Endowment for International Peace 2019, 22.

23 Striegher J, 'Violent-extremism: An examination of a definitional dilemma' Australian Security and Intelligence Conference, Perth, 30 November 2015 - 2 December 2015, 78.

24 United Nations Development Programme, Preventing violent extremism through promoting inclusive development, tolerance and respect for diversity, 2016, 8.

25 International Organization for Migration, Youth violence and the challenges of violent extremism in Zinder, 2018,50 .

Vol. 6:1 (2021) p. 200 
of marginalisation and unresponsive government functionaries. ${ }^{26}$ Marginalisation often leads to grievances which lead to conflicts. According to Edward Azar, protracted social conflict arises as a result of the historical legacy of "divide and rule", unresponsive government, and denial of basic human needs, especially development. ${ }^{27}$ This includes political inclusivity and economic participation that enhances social justice and, eventually, human development. ${ }^{28}$

Given the complex nature of the new war, traditional notions of security focusing on external conventional threats will not provide a comprehensive solution for both the state and the people. ${ }^{29}$ Addressing violent extremism requires innovation on how to win the hearts and minds of the people. It requires a human security approach which brings people at the centre of security. This is because threats to law and order from internal and external actors have become complex to the extent of challenging the survival of the state. ${ }^{30}$ Human security, as articulated in the UNDP's 1994 Human Development Report, advocates for a shift from state-centric to people-centred approach to security and equates security with 'people rather than territories, with development rather than arms'. ${ }^{31}$ The concept of human security revolves around the importance of affording people 'freedom from fear' and 'freedom from want'. ${ }^{32}$

Further, the International Covenant on Civil and Political Rights recognizes that human security exists only where conditions for its prosperity are created. ${ }_{33}$ Both the Atlantic Charter and the African Union Agenda 2063 on the 'The Africa We Want' recognise the same. ${ }^{34}$ The Constitution of Kenya (2010) also alludes to the progressive thinking around individual rights, community rights and the notion of security. In particular, the rights essential to individual security that are protected include, alongside other rights that fall within the umbrella of freedom from fear, the freedom from torture, degrading treatment or

26 United Nations Development Programme, Preventing violent extremism through promoting inclusive development, tolerance and respect for diversity, 2016, 23.

27 Azar E, Jureidini P and McLaurin R, 'Protracted social conflict; Theory and practice in the Middle East', 8(1) Journal of Palestine Studies, 1978, 45-47.

28 Ramsbotham O, 'The analysis of protracted social conflict: A tribute to Edward Azar', 31(1) Review of International Studies, 2005, 113.

29 Whitaker B, 'Reluctant partners: Fighting terrorism and promoting democracy in Kenya',258.

30 Fjäder C, 'The nation-state, national security and resilience in the age of globalisation', 2(2) Resilience: International policies, practices and discourses, 2014, 117.

31 United Nations Development Programme, Human Development Report, 1994, 1, 3, 22.

32 Acharya A, 'Human security: East versus West', 56(3) International Journal, 2001, 449-450.

33 International Covenant on Civil and Political Rights, 1976, 1.

34 - < https://www.unsecretariat.net/sections/history-united-nations-charter/1941-atlantic-charter/ index.html>- on 5 August 2020. African Union Commission, Agenda 2063: The Africa we want, April 2015,6 . 
punishment and the right to a fair trial. ${ }^{35}$ Freedom from want, on the other hand, encompasses economic and social rights, access to resources, poverty alleviation and sustainable human development.

There are seven essential characteristics of human security. ${ }^{36}$ These characteristics can be a function of either freedom from want or freedom from fear. The first function of freedom from want is economic security, which implies ensuring basic income that meets people's needs, guaranteeing adequate housing and a decent standard of living, employment opportunities, and social justice through equality and fairness in the distribution of resources and returns. ${ }^{37}$ The second function is food security which requires all people to have the purchasing power necessary to obtain basic food at all times. ${ }^{38}$ Thirdly, environmental security which aims to protect people from the ravages of the natural environment caused by individuals or the state and to conserve environmental resources. ${ }^{39}$ The fourth function is health security which requires adequate health care for all individuals and taking preventive measures to reduce the spread of diseases. ${ }^{40}$ All these contribute either directly or indirectly to human development at the basic level.

On the other hand, the functions of freedom from fear include, firstly, personal security which aims to protect people from physical and psychological violence whether from the state, external states, or from violent individuals. ${ }^{41}$ The second is community security which is concerned with the individual's sense of belonging in society. It aims to ensure healthy social relationships and to protect people from national, religious, and ethnic intolerance. ${ }^{42}$ Lastly, political security is concerned with upholding people's right to express their opinions and protecting them from repression. ${ }^{43}$ These promote tolerance of diversity both at the individual and at community levels. This is important because without

\footnotetext{
Article 25, Constitution of Kenya (2010).

36 Jolly R and Deepayan R, The human security framework and national human development reports: A review of experiences and current debates, United Nations Development Programme National Human Development Report Unit, Occasional Paper 5, May 2006, 4, http://hdr.undp.org/sites/ default/files/nhdr_human_security_gn.pdf on 5 August 2020.

37 International Committee of the Red Cross, What is Economic Security? 18 June 2015 https:/ /www.icrc. $\mathrm{org} /$ en/document/introduction-economic-security on 26 December 2020.

38 Food and Agriculture Organisation, Policy brief on Food Security, 2006, 1.

39 https://www.informea.org/en/terms/environmental-security/publications >- on 26 December 2020.

40 https://www.who.int/health-topics/health-security/\#tab=tab_1 on 26 December 2020.

41 https://definitions.uslegal.com/p/personal-security/ on 26 December 2020.

42 United Nations Development Programme, Community Security -https://www.undp.org/content/ undp/en/home/2030-agenda-for-sustainable-development/peace/rule-of-law--justice--securityand-human-rights/community-security.html on 26 December 2020.

43 https://www.gdrc.org/sustdev/husec/z-categories.html on 3 January 2021.
}

Vol. 6:1 (2021) p. 202 
tolerance, inclusivity of persons or communities in their own capacities is overlooked which often leads to marginalisation.

The Security Council meeting at the level of Heads of State and Government at the 2005 World Summit, adopted a resolution on conflict prevention, particularly in Africa, which pointed out that peace, security and development are mutually reinforcing. ${ }^{44}$ Furthermore, that a comprehensive strategy is needed to address the root causes of armed conflict, political and social crises in a comprehensive manner, by promoting sustainable development, poverty eradication, national reconciliation, good governance, democracy, gender equality, the rule of law and respect for and protection of human rights. ${ }^{45}$ The United Nations General Assembly resolution 66/290 of 2012 was an important milestone as it described human security as 'the right of people to live in freedom and dignity, free from poverty and despair.' ${ }^{46}$ This was reinforced by the UN Secretary-General who mentioned that human security, national security and global security are indivisible and that when people fear for their lives, their communities, societies and countries are also at an increased risk. ${ }^{47}$ Similarly, when people enjoy safety, so do their countries and the world. ${ }^{48}$

\section{Historical Marginalisation of Northern Frontier Counties}

For one to understand the dynamics of countering violent extremism in the Northern Frontier Counties, it is important to consider the region's uniqueness. The Northern Frontier Counties are situated in the North-Eastern region of Kenya. It is an important region that has a different geopolitical and security significance due to its proximity to Ethiopia to the North and Somalia to the East. During the colonial era, the region was referred to as the Northern Frontier Districts (NFDs). ${ }^{49}$ The Northern Frontier Counties (NFCs) are inhabited by Cushitic communities and their economic occupation is characterised by nomadic pastoralism. This frontier region has been significantly affected by the threats of violent extremism. ${ }^{50}$

44 UNSC S/RES/1625 (2005) Strengthening the effectiveness of conflict prevention in Africa, 1.

45 UNSC 1625 (2005), 1.

46 UNGA, Human Security, UN A/RES/66/290 (10 September 2012).

47 Rydell R, "The Guterres disarmament agenda and the challenge of constructing a global regime for weapons' 3 Journal for peace and nuclear disarmament 1, 2020, 25.

48 United Nations Secretary-General, Remarks at the University of Geneva on the launch of the Disarmament Agenda, 24 May 2018, - < https://www.un.org/sg/en/content/sg/ speeches/2018-05-24/launch-disarmament-agenda-remarks >- on 31 January 2021.

49 Northern Frontier District of Kenya, vol 248, Hansard 3 April 1963.

50 United Nations Development Programme, Support to the prevention of violent extremism in Kenya, 1.

Vol. 6:1 (2021) p. 203 
The NFCs are characterised by political, economic and security challenges that began from the colonial period and which have continued into contemporary times. The relationship between the post-independence government and the people of the Northern Frontier Counties has been characterised by suspicion and mistrust. ${ }^{51}$ This suspicion and mistrust can be traced to the colonial era where the NFCs were administered separately from the rest of the country. To guarantee the effectiveness of the separate administration policy, the British colonial authority established local administration and state-society relations through the 1902 Outlying District Ordinance, 1926 Closed District Ordinance and the 1934 Special District Administration Act. ${ }^{52}$ The Ordinances impacted individual and community freedom significantly. The socio-economic impact on the nomadic pastoral livelihood cannot be overemphasised. In particular, the Ordinances hampered the movement of goods and services, which contributed to a reduced standard of living. ${ }^{53}$

The British colonial authority was motivated by the need for a security buffer against Ethiopia to the North and the Italian colony of Somalia, given fragile security and geopolitical dynamics. ${ }^{54}$ In addition, the harsh weather and topographical conditions did not motivate the colonial government to sustain the administration and integration of this region with the rest of Kenya. ${ }^{55}$ Farson captured the emerging distinct identity between NFC and the rest of the country as 'one half of Kenya about which the other half knows nothing and seems to care even less'. ${ }^{56}$ This is an indication of the political, economic and security marginalisation.

Upon independence in 1963, the government was faced with a dilemma on how to handle the separate identity of the Northern Frontier Districts. ${ }^{57}$ The people of the frontier region demanded self-determination and secession which was based on the administrative and political isolation caused by the Outlying District Ordinance of 1902, the Closed District Ordinance of 1926 and

51 Arero $\mathrm{H}$, 'Coming to Kenya: Imagining and perceiving a nation among the Borana of Kenya', 1(2) Journal of Eastern African Studies, 2007, 297.

52 Ahmed Issack Hassan, North Eastern Province and the constitutional review process: Lessons from history' unpublished, Nairobi, 2006, 4.

53 Ahmed Issack Hassan, North Eastern Province and the constitutional review process: Lessons from history', 21.

54 Castagno A, 'The Somali-Kenyan controversy: Implications for the future' 169.

55 Castagno A, 'The Somali-Kenyan controversy: Implications for the future' 170.

56 Farson, J, Last Chance in Africa, llarcourt, Brace and Company, New York, 1950, 260.

57 Nzau M and Guyo M, 'The challenge of securing Kenya: Past Experience, Present Challenges and Future Prospects' 2(1) The Journal of Social Encounters, 2018, 41.

Vol. 6:1 (2021) p. 204 
the Special District Administration Ordinance of 1934. ${ }^{58}$ These laws separated the Northern Frontier District from the rest of Kenya and further divided the pastoral communities into controlled grazing zones where their land was taken away from them for the benefit of the colonialists. ${ }^{59}$ All this led to a state of resentment and a group of people who were focused on self-determination. The union of the Italian Somaliland and British Somaliland and the subsequent independence of Somalia culminated into the Shifta war. ${ }^{60}$ This secessionism was opposed by the Kenya African National Union (KANU) and the Kenya African Democratic Union (KADU) at the Lancaster House Conference of $1960 .{ }^{61}$ They wanted to use these areas as buffer zones to protect the capital city-security in this instance served the interest of the government and not the local people. ${ }^{62}$

The decision not to implement the outcome of the referendum on secessionism sparked an outrage and a confrontation where the Northern Frontier District leaders were detained. This ended in a high-handed security intervention. ${ }^{63}$ It further led to an insurgency warfare between the Government of Kenya and the NFC rebel movement backed by Somalia based on politics of identity and common decent. ${ }^{64}$ Between 1963 and 1968, the pastoral community in NFC endured the shifta war that was fought by an organised group from the former Northern Frontier Districts that supported the notion of secessionism. ${ }^{65}$ The community endured twin agony.

While the insurgents punished those suspected of not supporting their views of secessionism, ${ }^{66}$ security forces also punished innocent people because

58 Khalif Z, 'Pastoral transformation: Shifta-war, livelihood, and gender perspectives among the Waso Borana in Northern Kenya' published, Norwegian University of Life Sciences, Ås, 2010, 5.

59 Khalif Z, 'Pastoral transformation: Shifta-war, livelihood, and gender perspectives among the Waso Borana in Northern Kenya', 7.

${ }_{60}$ Chau D, 'At the crossroads of culture? A historic and strategic examination of Kenya-Somalia relations', 1(1) Journal of the Middle East and Africa, 2010, 68-69.

${ }_{61}$ Whittaker H, 'The socioeconomic dynamics of the Shifta conflict in Kenya', 53(3) The Journal of African History, 2012, 392.

62 Vision 2030 development strategy for Northern Kenya and other arid lands, March 2012, 11 -< https://www.ndma.go.ke/index.php/resource-center/policy-documents/send/44-policy-documents/4300-vision-2030-development-strategy-for-asals >- on 7 August 2020.

63 Khalif Z, 'Pastoral transformation: Shifta-war, livelihood, and gender perspectives among the Waso Borana in Northern Kenya', 6.

${ }_{64}$ Lochery E, 'Rendering difference visible: The Kenyan state and its Somali citizens', 111(445) African Affairs, 2021, 621; Chau D, 'At the crossroads of culture? A historic and strategic examination of Kenya-Somalia relations', 68-69

65 Chau D, 'At the crossroads of culture? A historic and strategic examination of Kenya-Somalia relations', 70-74

${ }^{66}$ Oba G and Khalif Z, 'Gaafa dhaabaa - the period of stop: Narrating impacts of shifta insurgency on pastoral economy in Northern Kenya, c. 1963 to 2007', 3(14) Pastoralism: Research, Policy and Practice, 2013, 2. 
they were suspect of being sympathisers. ${ }^{67}$ The punitive measures from security forces were from a narrow logic of the insurgents sharing a common identity with the people. This conflict led to the displacement of the community which forced them into security establishments in Merti, Garbatulla and Madogashe. This was a time referred to as gaafa dhaabaa, which meant 'the period of stop'the stop of pastoral production and human survival among others and, not long after, their pastoral economy was shattered. ${ }^{68}$ This period led to the shift in population from rural areas to local trading centres, the reduction of their herds and an impoverished population that began to heavily rely on external food aid. ${ }^{69}$

Large scale conflict ended in 1967, when the Zambian President Kenneth Kaunda mediated peace talks between Somalia and Kenya which culminated in the signing of a 'Memorandum of Understanding' (the Arusha Memorandum) which spelt out terms of the cessation of hostilities and an official ceasefire. ${ }^{70}$ However, unlike a classical resolution of conflict, no post-conflict reconstruction and resettlement arrangement was made. ${ }^{71}$ The conflict has inevitably resulted in an atmosphere of loss of confidence between the state and the people. The relationship between the government and the people of the Northern Frontier Counties continues to be that of suspicion and mistrust. ${ }^{72}$

Post-independence, the immediate administration was not quite responsive-a similarity with the colonial times. There was no administrative justice and especially with the enactment of the emergency laws of 1966 which provided for instances in which the fundamental human rights of the person could be violated. ${ }^{73}$ The laws enhanced powers of search without warrant, arrest, detention for up to fifty-six days without trial and a death sentence for unlawful possession of firearms. ${ }^{74}$ The regulations also created 'prohibited' zones along the KenyanSomali border where unauthorized entry was punishable by a life sentence. ${ }^{75} \mathrm{In}$

67 Oba G and Khalif Z, 'Gaafa dhaabaa - the period of stop: Narrating impacts of shifta insurgency on pastoral economy in Northern Kenya, c. 1963 to 2007', 2.

68 Oba G and Khalif Z, 'Gaafa dhaabaa - the period of stop: Narrating impacts of shifta insurgency on pastoral economy in Northern Kenya, c. 1963 to 2007’, 5.

69 Dahl G, 'Suffering grass: Subsistence and society of Waso Borana', Published, Department of Social Anthropology, University of Stockholm, Stockholm, 1979, 203.

70 Whittaker H, 'The socioeconomic dynamics of the Shifta conflict in Kenya', 402.

71 Nzau M and Guyo M, 'The challenge of securing Kenya: Past Experience, Present Challenges and Future Prospects', 41.

${ }^{72}$ Arero H, 'Coming to Kenya: Imagining and perceiving a nation among the Borana of Kenya' 297.

73 Whittaker H, 'The socioeconomic dynamics of the Shifta conflict in Kenya', 403

${ }^{74}$ Human Rights Watch, 'Bring the gun or you'll die' 29 June 2009, 13 — https://www.hrw.org/ reports/kenya0609web.pdf on 11 August 2020.

75 Human Rights Watch, 'Bring the gun or you'll die' 29 June 2009, 13 —https://www.hrw.org/ reports/kenya0609web.pdf on 11 August 2020.

Vol. 6:1 (2021) p. 206 
such areas, development was not a priority for those on the authoritarian seat but that of maintenance of law and order. ${ }^{76}$ The security that was aimed at was highly state-centric. Khalif and Oba noted that the shifta activities were driven in part by local grievances, as they were a reflection of the unsettled borders and frontiers in the Horn of Africa resulting from political instability Discrimination on the basis of identity, marginalisation, and underdevelopment through laws, government policies and other administrative practices were also the basis of grievances. ${ }^{77}$

Much later after the post-1960 conflict, the adversity of a state centric security practice also played out in the Wagalla massacre incident. The Wagalla massacre of 1984 saw the murder of many civilians in the name of a security operation that was intended to recover guns. ${ }^{78}$ Some of the residents who did not have the guns opted to buy and then surrender them to the security forces so that they could stop being tortured and also that they could recover the identity cards that they had earlier given up. ${ }^{79}$ One may then think that there are perhaps other underlying issues that drove such an excursion. It would be fundamental to call upon the Truth Justice and Reconciliation report as a 'part' witness to the event that took place during the Wagalla massacre. It is documented that Ambassador Bethuel Kiplagat denied attending a security meeting that had taken place in North Eastern Kenya a few days before the Wagalla Massacre. ${ }^{80}$ He only admitted to having attended it after being confronted with evidence but denied that the meeting was in order to discuss 'a security operation'. Correspondingly, the Provincial Commissioner in North Eastern Province, Benson Kaaria, defended the 'security operation' as successful even though more than 57 people were killed and only four guns recovered. ${ }^{81}$

76 Refugee Review Tribunal Australia, KEN 33956, Kenya, 3 November 2008, 6 < $<$ https://www. ecoi.net/en/file/local/1131966/1930_1292341414_ken33956.pdf>- on 1 February 2021.

77 Nzau M and Guyo M, 'The challenge of securing Kenya: Past Experience, Present Challenges and Future Prospects', 41.

78 Anderson D, 'Remembering Wagalla: State violence in Northern Kenya, 1962-1991', 8(4) Journal of Eastern African Studies, 2014, 664.

79 According to the Human Rights Watch, In some communities, elders pleaded with the commanders to relent and negotiated the release of their men in return for the surrender of the elders' identity cards, redeemable upon the production of weapons within three days. With the blessing of military commanders, families organized themselves, recovered some weapons from the bush, and purchased others from Somalia in order to hand them over to the police and army and reclaim their identity cards'. See, Human Rights Watch, 'Bring the gun or you'll die' 29 June 2009, 13 — https:/ / www.hrw. org/reports/kenya0609web.pdf on 11 August 2020.

80 Truth, Justice, and Reconciliation Commission, Final Report - TJRC Report Volume 3, Chapter Three, 2013, para.42.

81 Truth, Justice, and Reconciliation Commission, Final Report - TJRC Report Volume 3, Chapter Three, 2013, para.46. 
The unjustifiable marginalisation based on the identity of the people of the Northern Frontier Counties was further captured in the Truth, Justice and Reconciliation Report. The government was found to have more or less accepted the discriminatory practice against Kenyans on the basis of their ethnicity by requiring Kenyans of Somali descent to carry a special pass. ${ }^{82}$ It is a reminder of the historical colonial past where a separate identity among Kenyans was forged via government policies. ${ }^{83}$ The government claimed that requiring such passes assisted in distinguishing between Kenyans of Somali origin who are legally present and the Somalis who were not from Kenya, who may not be legally present. However, local Kenyans attribute this to more sinister motives. ${ }^{84}$ On the other hand, the spread of universities in Kenya excluded the Northern part of the country with most of them located within Nairobi and its vicinity. ${ }^{85}$ A comparison of the former Northern Frontier Districts and the former white highlands presents a poverty index which shows the disparity of income with Mandera and Wajir among the leading counties in the chart as opposed to the former white highlands. ${ }^{86}$

\section{Violent Extremism and Mitigation Measures in NFCs}

Due to historical marginalisation and deprivation, there has been an uprise of radicalisation among youths in recent years. ${ }^{87}$ The different state of play in this region has birthed a fragile region which can be manipulated by an organised criminal group. The lack of a responsive government policy in the NFCs and marginalsation based on one's identity are some of the causes of this fragility. An immediate example would be that of the Operation Usalama Watch which led to the discrimination against those of Somali descent. ${ }^{88}$ The civilians suffered

82 Refugee Review Tribunal Australia, RRT Research Response, 3 November 2008, — < https://www. ecoi.net/en/file/local/1131966/1930_1292341414_ken33956.pdf>- on 1 February 2021.

83 Nzau M and Guyo M, 'The challenge of securing Kenya: Past Experience, Present Challenges and Future Prospects', 41.

84 Truth, Justice, and Reconciliation Commission, Final Report - TJRC Report Volume 3, Chapter Three, 2013, para.43.

85 Truth, Justice, and Reconciliation Commission, Final Report - TJRC Report Volume 3, Chapter Three, 2013, para.84.

86 Muda C, 'Report on richest and poorest counties out' Business Daily, 23 March 2018 - https:// www.businessdailyafrica.com/bd/economy/report-on-richest-and-poorest-counties-out--2195026 on 5 August 2020.

87 Hellsten S, 'Radicalisation and terrorist recruitment among Kenya's youth', The Nordic Africa Institute, February 2016, 4 - https://www.files.ethz.ch/isn/196275/FULLTEXT01.pdf on 3 January 2021.

88 Lind J, Mutahi $\mathrm{P}$ and Oosterom M, 'Killing a mosquito with a hammer: Al-Shabaab violence and state security responses in Kenya', 5(2) Peacebuilding, 2017, 129-130.

Vol. 6:1 (2021) p. 208 
from arbitrary arrests, extrajudicial killings and torture. ${ }^{89}$ Generally, the suspicion and mistrust between the residents of the Northern Frontier Counties and the national government has often led to friction and tension between the state and the community.

The propagation of violent extremism is premised on the presence of a youth bulge and the prevalence of unemployment. ${ }^{90}$ These two factors are present in the Northern Frontier Counties due to systematic marginalisation. ${ }^{91}$ Additionally, the lack of equal opportunities has resulted in a new form of closed region similar to the colonial era. ${ }^{92}$ The few educated remain unemployed because of limited job opportunities in the region and the lack of equitable opportunities. This has led to sustained grievances. Employment is critical both for livelihood sustenance and to ensure youths' energy is directed towards meaningful activities. However, given the lack of employment and high poverty levels, Al-Shabaab has been able to exploit this gap and radicalize youths.

Al-Shabaab is a group that perpetrates violence primarily in Somalia as a means of attaining their objectives of setting up a Somali Caliphate of the Wahhabi Islamic sect that not only establishes control over Somalia but also other countries in the region. ${ }^{93}$ Given their international agenda and the close proximity of Kenya to Somalia, the Al Shabaab has been able to infiltrate Kenya through the Northern Frontier Counties. ${ }^{94}$ Their aim of winning over the local people and establishing their foothold in the region is achieved by manipulating local grievances. ${ }^{95}$ Over the years, Al Shabaab has been able to perpetrate acts of terror such as strings of attacks in Nairobi, Mombasa, Garissa, Lamu, Mandera and Wajir. ${ }^{96}$

89 Lind J, Mutahi P and Oosterom M, 'Killing a mosquito with a hammer: Al-Shabaab violence and state security responses in Kenya', 130-131

90 Youth NEET in Kenya, Understanding values, capabilities and barriers towards achieving career and life goals, Dalberg Research Limited, London, 2019, 27.

91 Youth NEET in Kenya, Understanding values, capabilities and barriers towards achieving career and life goals, Dalberg Research Limited, London, 2019, 27.

92 Commission on Revenue Allocation, 'Historical injustices: A complementary indicator for distributing the equalisation fund', CRA Working Paper No. 2012/02, 2012, 28 — https://devolutionhub.or.ke/ resource/historical-injustices-a-complementary-indicator-for-distributing-the-equalization-fund.

93 Ali A, 'The Al-Shabaab Al-Mujahidiin - A profile of the first Somali terrorist Organisation' Institut für Strategie - Politik - Sicherheits - und Wirtschaftsberatung, IGAD Capacity Building Programme against Terrorism, 2008, 3 - https://www.files.ethz.ch/isn/55851/AlShabaab.pdf - on 4 February 2021.

94 Burns A, 'Feeling the pinch: Kenya, Al-Shabaab, and the East Africa's refugee crisis', 27(1) Refuge: Canada's journal on Refugees, 2010, 5.

95 Wabwire A, 'Resource distribution and security in Kenya: A case study of North Eastern Kenya' Unpublished, United States International University, Nairobi, 2016, 19.

96 Bar J, 'The problem of Islamic terrorism in Kenya in terms of regional security in East Africa', 42 Politeja, 2016, 148-149. 
To grapple with the challenges of the rise of violent extremism and terrorism in the region, Kenya has enacted a number of legislations and created institutions to deal with the same. Before the express legislation making the National Counter Terrorism Centre, hereafter (NCTC), the coordinator of all government actions to counter violent extremism and before the passing of the Prevention of Terrorism Act (2012), there was difficulty in charging persons suspected to have committed terrorism related crimes. ${ }^{97}$ This was due to a rejection of a law on the basis of its identical nature with that of the United States. ${ }^{98}$ On the other hand, the Prevention of Terrorism Act was rejected at some point due to concern by different stakeholders on its implication for civilians. This is because its definition of terrorism was vague and it granted the police special powers of arrest, investigation and detention. ${ }^{99}$ These provisions were seen to be easily used against ordinary civilians of Somali decent. ${ }^{100}$ This Act was however passed after the attainment of understanding among different parties. ${ }^{101}$

The Westgate Mall attack that occurred in 2013 took place in the wake of the Prevention of Terrorism Act (2012) (against Kenya's military presence in Somalia). ${ }^{102}$ This led to the launch of Operation Usalama Watch in 2014 in order to increase in-state security. ${ }^{103}$ This initiative was operationalized militarily, a move that was widely condemned by international human rights groups as it led to the violation of civilian's rights. 6000 additional security officers were deployed in Eastleigh to implement this initiative. ${ }^{104}$ The actions taken by the security forces in this area led to a further marginalisation and exclusion of a people that had already suffered the same for many years. The operation comprised cases of arbitrary arrests of at least 4000 Somalis, ${ }^{105}$ unlawful deportation, extrajudicial

97 Kariuki A, 'Challenges of combating homegrown terrorism in Kenya: A youth radicalisation perspective', Published, Walden University, Minneapolis, 2019, 4.

98 Kariuki A, 'Challenges of combating homegrown terrorism in Kenya: A youth radicalisation perspective’, 4.

99 Princeton School of Public and International Affairs, Preventing violent extremism: Lessons from Kenya, January 2020, 20.

100 Princeton University, Woodrow Wilson School of Public and International Affairs, Preventing violent extremism: Lessons from Kenya, January 2020, 20.

101 Kariuki A, 'Challenges of combating homegrown terrorism in Kenya: A youth radicalisation perspective', 4.

102 Princeton University, Woodrow Wilson School of Public and International Affairs, Preventing violent extremism: Lessons from Kenya, January 2020, 20.

103 Williams P, 'After Westgate: Opportunities and challenges in the war against Al-Shabaab', 90(4) International Affairs (Royal Institute of International Affairs), 2014, 908.

104 Kenya National Commission on Human Rights, Return of the Gulag, July 2014, 3 -http://knchr. org/Portals/0/CivilAndPoliticalReports/Report $\% 20$ of $\% 20$ KNCHR $\% 20$ investigations $\% 20$ on $\% 20$ Operation\%20Usalama\%20Watch.pdf?ver=2018-06-06-194906-830 on 2 January 2021.

105 Kenya National Commission on Human Rights, Return of the Gulag, July 2014, 3 — http://knchr.

Vol. 6:1 (2021) p. 210 
killings, torture by security forces ${ }^{106}$ and the discrimination against ethnic Somalis and those of the Muslim faith. ${ }^{107}$

Similarly, the Garissa University attack was also handled in a manner that led to many grievances by the communities living in Garissa, Wajir and Mandera. ${ }^{108}$ The Human Rights Watch documented the forceful disappearance, killing and torture of many who were thought to have links to Al-Shabaab. The community reported that they felt 'unfairly targeted and marginalised'. ${ }^{109}$

The government had developed hard-security strategies to address the breakdown of law and order. ${ }^{110}$ The reliance on state-centric security measures compromised both freedom from fear and freedom from want. This has given rise to various forms of human insecurity that have had detrimental effects on development in the region. Poverty in this sense is not only viewed from an economic viewpoint but also on account of other factors that contribute to a quality of life. The Prevention of Torture Act, for instance, has provisions that should ideally protect the community's freedom from fear. ${ }^{111}$ However, the culture of arbitrary arrests, extra-judicial killings and torture which has been normalized contradicts this. ${ }^{112}$ This norm has been perceived by the local population to be a form of collective punishment and has led to further strain in the relationship between the local NFC population and the national government. ${ }^{113}$ Notwithstanding, it has further violated their constitutional rights to not be deprived of freedom arbitrarily or without just cause, to not be detained

org/Portals/0/CivilAndPoliticalReports/Report $\% 20$ of $\% 20$ KNCHR $\% 20$ investigations $\% 20$ on $\% 20$ Operation\%20Usalama\%20Watch.pdf?ver=2018-06-06-194906-830 on 2 January 2021.

106 - https://www.amnesty.org/en/latest/news/2014/05/kenya-somalis-scapegoated-counter-terrorcrackdown/ on 5 January 2021.

107 Kenya National Commission on Human Rights, Return of the Gulag, July 2014, 10 — http://knchr. org/Portals $/ 0 /$ CivilAndPoliticalReports/Report $\% 20$ of $\% 20$ KNCHR $\% 20$ investigations $\% 20$ on $\% 20$ Operation\%20Usalama\%20Watch.pdf?ver=2018-06-06-194906-830 on 2 January 2021.

108 Abdi N, ‘Wounds of Garissa Attack, Four Years On’ Human Rights Watch, 8 April 2019 — https:/ / www.hrw.org/news/2019/04/08/wounds-garissa-attack-four-years on 2 January 2021.

109 Abdi N, 'Wounds of Garissa Attack, Four Years On', Human Rights Watch, 8 April 2019 —https:// www.hrw.org/news/2019/04/08/wounds-garissa-attack-four-years on 2 January 2021.

110 Institute for Security Studies, Preventing violent extremism in Kenya, May 2017, 5.

111 Section 6, Prevention of Torture Act (2017).

112 Human Rights Watch, Kenya: Security forces arbitrarily detaining people; Terrorist Attacks do not justify heavy handed response, 28 November 2011 - https://www.hrw.org/news/2011/11/28/ kenya-security-forces-arbitrarily-detaining-people on 31 December 2020.

113 Abdi N, 'Wounds of Garissa Attack, Four Years On' Human Rights Watch, 8 April 2019 -https:// www.hrw.org/news/2019/04/08/wounds-garissa-attack-four-years on 2 January 2021.; Life and Peace Institute Centre for Christian-Muslim Relations in Eastleigh, Exploring peaceful coexistence in Nairobi's urban settlements, 2016, 11. 
without a trial and not to be subjected to any form of violence and torture. ${ }^{114}$ Moreover, their rights as arrested persons were also infringed upon together with their right to a fair hearing ${ }^{115}$

Lack of freedom from want is a classic case of marginalisation that compromises state and society relations leading to vulnerability in the region. The historical 'closed' nature of the region due to the many years of exclusion continues to be perpetrated to a large extent even after independence. Due to insecurity in the region, there is marginal access to basic infrastructural development and poor quality of service delivery especially in the health and education sectors. ${ }^{116}$ From this, it is evident that distribution of resources heavily relies on security. 117 Nonetheless, the lack of the resources themselves equally contribute to diminished human security thus creating a vicious cycle.

The shattering of the community's economy from the Shifta period is yet to be recovered from. ${ }^{118}$ The continued insecurity faced by the community has been an impediment to their sustenance. Food insecurity and reliance on food aid continue to be an ever-present phenomenon. In as much as the food insecurity can be classified as a natural disaster, there are human actions that catalyse this situation. Investments in building a resilient community have not been a priority. The effects can be seen from the number of people living below the poverty line. ${ }^{119}$ Unfortunately, even those who move to urban centres in search of livelihood are a target because of their descent. ${ }^{120}$ After the attack occurred in Eastleigh on 18 November 2012, the residents of Somali origin therein suffered torture from the Kenyan police and the looting of their shops by youth gangs. ${ }^{121}$ From an economic perspective, the attack had detrimental effects on their search for a living. Moreover, in light of the Garissa attack, many civilians were

\footnotetext{
114 Article 29 (b), Constitution of Kenya (2010).

115 Article 49-50, Constitution of Kenya (2010).

116 Hellsten S, 'Radicalisation and terrorist recruitment among Kenya's youth', The Nordic Africa Institute, February 2016, 3 - https://www.files.ethz.ch/isn/196275/FULLTEXT01.pdf on 3 January 2021.

117 Wabwire A, 'Resource distribution and security in Kenya: A case study of North Eastern Kenya' 25.

118 Oba G and Khalif Z, 'Gaafa dhaabaa - the period of stop: Narrating impacts of shifta insurgency on pastoral economy in Northern Kenya, c. 1963 to 2007', 5.

119 Diwakar V and Shepherd A, 'Understanding poverty in Kenya: A multidimensional analysis report' Chronic Poverty Advisory Network, 2018, 12 - https://sidase-wp-files-prod.s3.eu-north-1. amazonaws.com/app/uploads/2020/12/01095836/kenya-mdpa.pdf on 13 February 2021.

120 Human Rights Watch, You are all terrorists, 29 May 2013, 14 -https://www.refworld.org/ docid/51f121744.html on 4 January 2021.

121 Human Rights Watch, You are all terrorists, 29 May 2013, 14 -https://www.refworld.org/ docid/51f121744.html on 4 January 2021.
}

Vol. 6:1 (2021) p. 212 
detained unlawfully and were only set free upon bribery. ${ }^{122}$ This is an injustice as these people seem to always be a target, yet they also suffer from economic deprivations.

In 2014, the Security Law Amendment Act fast-tracked the revision of twenty-one existing laws, and finally outlined the objectives, scope, and mandate of the NCTC to be a primary coordinating body for all counterterrorism efforts by the government. ${ }^{123}$ In 2016, the NSCVE, which resembled the 2015 UN Plan of Action to prevent violent extremism, was launched in Kenya. ${ }^{124}$ Among its many objectives was the use of soft security approaches that appear to be development-oriented. This includes the provision of education and life skills in order to mitigate the circumstances that lead to radicalization and extremism. ${ }^{125}$ This is what birthed the different County Action Plans on Prevention and Countering Violent Extremism in the various counties. These action plans are founded on pillars advanced by the NSCVE with the inclusion of additional pillars that are central to the community they refer to. ${ }^{126}$

\section{i. Isiolo case study}

This part focuses on Isiolo, a county that was comprised of the former Northern Frontier Districts and has a total of twelve pillars. Nine of these pillars were advanced by the NSCVE: faith-based and ideological factors; art and culture; education; psychosocial factors; legal and policy framework; media and online platforms; training and capacity building; political factors; and security. The additional three pillars which are county and national government relationship, women, and access to justice, are tailored to the needs of the community. ${ }^{127}$ The County Action Plan was advanced to bring different stakeholders on board in the fight against violent extremism. This is indeed a step towards a bottomup approach to tackle the root causes of violent extremism as it involves the

122 Wakube C, Nyagah T, Mwangi J and Attree L, 'Inside Kenya's war on terror: breaking the cycle of violence in Garissa' Saferworld: preventing violent conflict, building safer lives, $14-\mathrm{https}$ // static1.squarespace.com/static/58921b4b6b8f5bd75e20af7e/t/597f105886e6c03d8024f5 9b/1501499494866/breaking-the-cycle-of-violence-in-garissa-v2.pdf on 13 February 2021.

123 - < https://www.counterterrorism.go.ke/ >- on 4 January 2021.

124 Ogada M, 'A policy content evaluation of Kenya's national strategy to counter violent extremism' Centre for Human Rights and Policy Studies, Policy brief no. 9 of 2017, 2.

125 Ogada M, 'A policy content evaluation of Kenya's national strategy to counter violent extremism' Centre for Human Rights and Policy Studies, Policy brief no. 9 of 2017, 2.

126 Isiolo County Government, Isiolo county action plan on prevention and countering violent extremism, 20182022, 2018, 42.

127 Isiolo County Government, Isiolo county action plan on prevention and countering violent extremism, 20182022, 2018, 42.. 
members of the community, Civil Society Organisations, and the National government through the County administration to work together.

Some of the pillars ideally touch on key issues that would enhance the population's human security. Notably, most of the pillars lean towards freedom from fear rather than freedom from want. Illustratively, the pillar on security speaks to the culture of arbitrary arrests, profiling and detention without trial that the population has had to endure. Additionally, the pillar that advocates for access to justice acknowledges the grievances that the community has endured and that started from the era of the Shifta war. The legal and policy framework pillar also seeks to transform laws that would encourage marginalisation due to their discriminative nature. ${ }^{128}$ Further, the nature of the national and county government collaboration relationship may at times risk the exclusion of the community about which elders have complained that they are only called upon as a measure of last resort. ${ }^{129}$

However, the education pillar appears to be the only pillar under the umbrella of freedom from want. Even then, only indirectly. There is an absence of an economic pillar that caters for the (nomadic) livelihood of these communities. This fails to mitigate the high unemployment and high poverty levels experienced in this region that has been documented as among the main reasons for youth radicalisation. ${ }^{130}$

Moreover, there have been challenges facing the implementation of the Isiolo County Action Plan. Community members have complained about the police who are said to give false narratives of terrorism in order to enrich themselves. ${ }^{131}$ This is done by accusing the youth of crimes tied to terrorism in order to pressure them for bribes even when the allegations are false. ${ }^{132}$ This has had detrimental effects on efforts to curb violent extremism. With a deteriorated

128 Isiolo County Government, Isiolo county action plan on prevention and countering violent extremism, 20182022, 2018, 43-48.

129 Isiolo County Government, Isiolo county action plan on prevention and countering violent extremism, 20182022, $2018,31$.

130 Ministry of Education, Kenya, Prevention and management of emerging forms of violence in learning institutions in Kenya: Perceptions of education stakeholders, Situational Assessment Report, 2017, 25.

131 Turi G, 'Why have deployments of anti-terrorism police and community-police partnerships failed to stop recruitment by al-Shabaab?' Institute for Security Studies, 8 October 2020 — https:// issafrica.org/iss-today/violent-extremists-find-fertile-ground-in-kenyas-isiolo-county on 4 January 2021.

132 Turi G, 'Why have deployments of anti-terrorism police and community-police partnerships failed to stop recruitment by al-Shabaab?' Institute for Security Studies, 8 October 2020 — https:// issafrica.org/iss-today/violent-extremists-find-fertile-ground-in-kenyas-isiolo-county on 4 January 2021.

Vol. 6:1 (2021) p. 214 
relationship between the police and the population, this may create another gap that can be misused to radicalise the youth.

Drawing lessons from Canada, it would be important to first understand how this country has tried to mitigate the challenges of violent extremism through a human security approach. When the term "human security" was first coined in the 1990s by the United Nations Development Programme, it was among the first countries that embraced this concept. ${ }^{133}$ The then Foreign Minister of Canada, Lloyd Axworthy, greatly influenced the country's approach towards the achievement of this new goal when he mentioned that human security was more than the absence of military threat. Rather, it encompassed the security against economic privation, an acceptable quality of life, and guarantee of fundamental human rights. ${ }^{134}$

Over the years, Canada has faced different types of attacks within its borders. Most of the attacks Canada has experienced are by lone attackers who have been radicalised. ${ }^{135}$ This phenomenon has posed challenges in curbing extremist activities due to the difficultly in identifying who specifically has been radicalised. Adapting to these threats, Canada established a bottom-up approach that was centred on the involvement of the community. This involves community-led and police-supported ${ }^{136}$ initiatives which were achieved through public and private partnership that includes NGO's, Civil Societies and the citizens themselves. These actors work closely with the Royal Canadian Mounted Police and the Ministry of Public Safety with whom they have had a good working relationship with for a long time. ${ }^{137}$ The inclusion of the members of the society in countering violent extremism has to some extent mitigated the consequences of a state centric approach that would have otherwise curtailed the citizen's freedom from fear.

Inclusivity of community members in the fight against violent extremism is the best way to ensure an effective and sustainable approach towards countering

133 Wethes S and Bosold D, 'Human security in practice: Canadian and Japanese experiences', 2005, 87 — file:///C:/Users/buter/Downloads/Human_Security_in_Practice_Canadian_and_Japanese_E. pdf on 4 March 2021.

134 Remacle E, 'Approaches to human security: Japan, Canada, and Europe in comparative perspective', 66 The Journal of Social Science, 2008, 9 -<https://core.ac.uk/download/pdf/234715572.pdf $>$ on 4 March 2021.

135 Jacoby T, 'How the war was 'one': Countering violent extremism and the social dimensions of counter-terrorism in Canada’ Journal for Deradicalisation, 2016, 281.

136 Fink N, Romaniuk P and Barakat R, Evaluating countering violent extremism programming: Practice and Progress, Center on Global Counterterrorism Cooperation, 2013, 8.

${ }^{137}$ Jacoby T, 'How the war was 'one': Countering violent extremism and the social dimensions of counter-terrorism in Canada' Journal for Deradicalisation, 2016, 294.

Vol. 6:1 (2021) p. 215 
violent extremism. This is because radicalisation takes place in a social setting stemming from societal grievances. This inclusivity can be achieved in different ways through the two pillars of human security discussed in this paper. From the perspective of freedom from fear, a collaborative structure that does not target nor profile the community can prove to be helpful. This is because it eliminates resentment rooted in discrimination that often is one of the causes of radicalisation. This resentment is often caused by the violation of fundamental human rights and freedoms.

To further break the cycle of radicalisation caused by marginalisation, it would be important to cater for the community's freedom from want. This is because some of the reasons for youth radicalisation stem from the hardships of life that often comprise economic difficulties due to unemployment which results in poverty. Development centred on improved educational facilities and employment opportunities are some of the long-term approaches that can be put in place. Generally, the inclusivity of the community and even of persons individually can help address the challenges of violent extremism faced by starting from the bottom with those who can be potentially radicalised.

\section{Recommendation and conclusion}

\section{i. Recommendations}

In the words of Kofi Annan:

'For too long, conflict in Africa had been seen as inevitable or intractable, or both. It was neither. Conflict in Africa, as everywhere, was caused by human action, and could be ended by human action'. 138

Following this statement, this paper has sought to bring to light the plight of a community that has not only been historically marginalised by the insurgency war but has also suffered the same treatment post-independence. One of the most important ways of winning the hearts and minds of the people in countering violent extremism is to focus on the root causes and drivers of violent extremism, not just the symptoms and resulting consequences. This is only possible by strengthening partnerships between the government and community. There is need for a proactive interaction between the political, religious, and traditional elders. This will instil a sense of collective action and ownership in affairs that affect the people. Of importance is the need to address issues such

138 United Nations, Press release SG/SM/6523, 16 April 1998.

Vol. 6:1 (2021) p. 216 
as the rule of law, marginalisation, the need for improved governance, the issue of corruption and the need for increased opportunities tailored to the needs of the community.

Moreover, there is need for a deeper understanding of the socio-economic and development issues of the Northern Frontier Counties with a view to developing critical interventions that will enhance human security and stability. Every step taken toward development is a step in reducing poverty and achieving economic growth which will ultimately contribute towards sustainable security and stability. Development planning and implementation will benefit a lot from public participation so that no one is left behind. Development programmes need to mainstream youth and women at the grass root levels in targeting unemployment and access to resources. This requires robust policy and a legal and institutional framework that includes all stakeholders, especially youth in political and socio-economic matters as a measure to prevent them from radicalization and recruitment to terrorist and organized criminal networks. Further, all development projects and programmes need to enhance peace building, community cohesion, and integration.

Given that instability in Somalia affects regional and international peace and security, the need for some practical steps in resolving the protracted conflict in Somalia cannot be over emphasised. This includes dialogue with Al Shabaab because military means cannot offer solutions to the current mutually hurting stalemate which can be unlocked through political settlement.

Security partnership and ownership is also important. There is need for a paradigm shift in managing security in the Northern Frontier Counties. The county leadership should be part of the regional and county security committee alongside the officials of the national government. This will allow the county leaders to make important inputs on security interventions because they understand the local context. In addition, the government should implement the existing legislation requiring cooperation between national and county governments such as County Policing Authorities, provided by the National Police Service Act, which gives the county and national government a cooperation framework to manage county policing. This will address the deteriorating confidence between the community and police and advance the human security approach - putting people at the centre of their security. 


\section{ii. Conclusion}

This paper has sought to help the reader understand the approaches in countering violent extremism in the Northern Frontier Counties. It is clear that the challenges facing security in the NFC and Kenya at large are unique and highly dynamic as they involve a complex array of actors and issues ranging from generational marginalisation, poverty and inequality, youth bulge, ethnic radicalization, to institutional weaknesses, proximity to Somalia and terrorism. Violent extremism and terrorism are emerging as a major threat to national cohesion and integration. However, the dynamic nature of the threats has not been addressed adequately due to economic, security, policy, and institutional lacunae. This paper has shown that the government has presided over uneven human development, which continues to undermine social justice, national cohesion, and integration. Unless this is addressed comprehensively, the perceived marginalisation of communities from the Northern Frontier Counties will continue to fuel mistrust between the state and society.

The paper has also shown that the administrative and security principles and practice in Northern Frontier Counties have been based on the narrow perspective of a state-centric approach. Consequently, countering violent extremism has remained detached from local needs, aspirations, and reality. While the nature of security has changed and become complex, this has not been matched by a comprehensive approach that takes into consideration the security of both the state and the society. The implication is that the state-centric approach alone has never secured the state nor will it ever. This is because countering violent extremism approaches cannot succeed in the long-term without addressing a range of factors, specifically political, socio-economic, and perception as well as ownership of security by the people. Therefore, innovative strategies are needed to unleash the potential of NFC to achieve sustainable development, peace, security and stability. 